\title{
Lowering rumen-degradable and rumen-undegradable protein improved amino acid metabolism and energy utilization in lactating dairy cows exposed to heat stress
}

\author{
J. D. Kaufman, K. G. Pohler, J. T. Mulliniks, and A. G. Ríus ${ }^{1}$ \\ Department of Animal Science, University of Tennessee, Knoxville 37996
}

\begin{abstract}
The objective of this study was to evaluate the effects of reducing dietary rumen-degradable protein (RDP) and rumen-undegradable protein (RUP) on protein and energy metabolism in heat-stressed dairy cows. Eighteen primiparous and 30 multiparous mid-lactation Holstein cows were used in a completely randomized design arranged in a $2 \times 2$ factorial $(n=12 /$ treatment). Cows were randomly assigned to 1 of 4 dietary treatments that included 2 levels of RDP (10 and 8\%; D) and 2 levels of RUP ( 8 and $6 \%$; U) of dry matter for $21 \mathrm{~d}$ as (1) 10D:8U, (2) 8D:8U, (3) 10D:6U, and (4) 8D:6U. Diets were isoenergetic and contained $50 \%$ forage and $50 \%$ concentrate (dry matter basis). Cows were housed in a freestall barn. Three weeks before start of treatments, all animals were fed the $10 \mathrm{D}: 8 \mathrm{U}$ diet and received supplemental cooling to prevent heat stress. During the treatment period, cows experienced a daily increment in temperature-humidity index from 74 to 82 for 1000 to $2000 \mathrm{~h}$. Blood samples were collected on d -1 and 21 of the treatment period to determine plasma concentrations of AA, glucose, insulin, fatty acids, and $\beta$-hydroxybutyrate. For primiparous cows, reducing from 10 to $8 \%$ RDP decreased insulin concentrations. For multiparous cows, we found significant RDP by RUP interactions for insulin, $\beta$-hydroxybutyrate, fatty acids, total essential AA, and 3-methylhistidine concentrations. Reducing from 10 to $8 \%$ RDP decreased insulin concentrations at $6 \%$ RUP, but concentrations did not change when reducing RDP at $8 \%$ RUP. Reducing from 10 to $8 \%$ RDP decreased $\beta$-hydroxybutyrate concentrations at $8 \%$ RUP, but concentrations did not change when reducing RDP at $6 \%$ RUP. Reducing from 10 to $8 \%$ RDP increased nonesterified fatty acid and total essential AA concentrations at 8\% RUP, but concentrations did not change when reducing RDP at $6 \%$ RUP. Reducing from 8 to $6 \%$ RUP decreased 3-methylhisti-
\end{abstract}

Received June 15, 2017.

Accepted September 16, 2017.

${ }^{1}$ Corresponding author: arius@utk.edu dine concentration at $8 \%$ RDP, but not at $10 \%$ RDP. Reducing from 8 to $6 \%$ RUP increased milk protein yield efficiency in primiparous and multiparous cows. These results indicate that reducing RDP and RUP lowers circulating insulin, which was associated with mobilization and utilization of fatty acids. Reduced RDP and RUP increases the use of AA to maintain milk protein synthesis and limit AA catabolism in cows exposed to warm climates.

Key words: amino acid, dairy cow, heat stress

\section{INTRODUCTION}

Dairy cows in negative energy balance rely on energy reserves to maintain homeostasis because the demand for energy exceeds that of energy intake; thus, fatty acids are mobilized from stored triglycerides in adipose tissue (Bell, 1995). During negative energy balance, low circulating insulin levels facilitate lipolysis and utilization of fatty acids in peripheral tissues (Bell, 1995; Randle, 1998). Lactating cows exposed to short-term periods of high environmental temperatures and humidity enter into negative energy balance. Although animals exposed to heat stress reduce feed intake, circulating insulin levels increase as part of an adaptive mechanism, altering metabolism of carbohydrates, lipids, and proteins (Rhoads et al., 2009; Wheelock et al., 2010). The cause for the rise of circulating insulin is not clear during heat stress, but elevated insulin, a known promoter of glucose uptake in skeletal muscle and adipose tissues, limits fuel availability for milk synthesis during heat stress. For example, the insulin promotes glucose disposal in peripheral tissues on heat-stressed animals (Rhoads et al., 2009; Sanz Fernandez et al., 2015). Therefore, metabolic and physiological adaptations during heat stress promote the use of nutrients in peripheral tissues and may reduce nutrient availability for milk synthesis (Rhoads et al., 2009; Wheelock et al., 2010).

As circulating glucose levels in ruminants are relatively low, particularly in early-lactation cows, insulin secretion is primarily regulated by rumen production 
and absorption of propionate (Manns and Boda, 1967). In addition to propionate, levels of MP supply control both secretion and plasma concentrations of insulin in growing heifers (Wiley et al., 1991) and lactating cows (Rius et al., 2010). For example, heifers supplemented with $250 \mathrm{~g} / \mathrm{d}$ of additional RUP increased secretion of insulin compared with a control diet (Wiley et al., 1991). Moreover, late-lactation primiparous cows supplemented with rumen-protected AA (i.e., $300 \mathrm{~g} / \mathrm{d}$ of formaldehyde-treated casein) showed a $40 \%$ increase in plasma insulin concentrations compared with nonsupplemented cows, and greater insulin concentrations were negatively correlated with milk and milk component yields (Hunter and Magner, 1988). Collectively, the increased circulating concentrations of insulin in these studies were likely caused by an increase in AA concentrations because insulin secretion responds to changes in plasma AA profile and concentrations (Kuhara et al., 1991). Therefore, with regard to the present study, we hypothesized that reduction of RDP and RUP would reduce plasma insulin concentrations and maintain nutrient availability to sustain synthesis of milk and milk components in heat-stressed lactating dairy cows. The objective of our study was to assess the effects of RDP and RUP on metabolic parameters that influence protein and energy use in lactating dairy cows.

\section{MATERIALS AND METHODS}

\section{Animals, Housing, and Treatments}

All experimental procedures were approved by the Institutional Animal Care and Use Committee of the University of Tennessee. Animals and experimental design of the study were previously described by Kaufman et al. (2017). Briefly, 18 primiparous (140 \pm 49 DIM) and 30 multiparous (126 \pm 47 DIM) Holstein cows were housed in a freestall barn at the East Tennessee AgResearch and Education Center, Little River Animal and Environmental Unit (Walland, TN). In a completely randomized design, cows were stratified into 4 treatment groups based on DIM, parity ( $\sim 5$ primiparous and 8 multiparous cows/treatment group), milk production, and BCS and randomly assigned to receive 1 of the 4 treatment diets arranged in a $2 \times 2$ factorial. Dietary treatments were formulated with 2 levels of RDP (10 and 8\%; D) and 2 levels of RUP ( 8 and $6 \%$; U) on a DM basis as (1) 10D:8U, (2) 8D:8U, (3) 10D:6U, and (4) 8D:6U. Diets were formulated to contain $50 \%$ forage and $50 \%$ concentrate on a DM basis, with the protein proportions manipulated by varying quantities of soybean meal, protected soybean meal (SoyPLUS; West Central Cooperative, Ralston, IA), fish meal, blood meal, and urea according to NRC (2001). Dietary composition was previously reported (Kaufman et al., 2017). Diets were mixed as a TMR and fed to each individual cow at $0900 \mathrm{~h}$ using an electronic feeding system (American Calan Inc., Northwood, NH). Feed was offered to attain 5 to $10 \%$ refusals each day. Cows were fed the 10D:8U diet from d 1 through 21 of the pretreatment period, followed by the respective experimental diets for an additional 21 d (i.e., treatment period). The NRC (2001)-predicted AA profiles as a proportion of MP from each dietary treatment are displayed in Table 1. Cows were milked twice daily at 0900 and $1900 \mathrm{~h}$ and milk production was automatically recorded at each milking. Milk sampling and analysis were previously reported (Kaufman et al., 2017).

\section{Environmental Management}

During the pretreatment period, cows received supplemental cooling by using fans starting at $>20^{\circ} \mathrm{C}$ of ambient temperature. Throughout the treatment period, all cows experienced $10 \mathrm{~h}$ of unabated daily summer temperatures from 1000 and $2000 \mathrm{~h}$. At 2000 to $1000 \mathrm{~h}$, temperature-humidity index (THI) ranged from 69 to 76 ; thereafter, the environment was at a THI range of 74 to 82 . Core body temperature and respiration rates were recorded to monitor thermal load during the treatment period and reported elsewhere, demonstrating cows were successfully exposed to heat stress (Kaufman et al., 2017).

\section{Blood Collection and Analyses}

Blood samples were collected from each cow by coccygeal venipuncture, after the morning milking, on $\mathrm{d}-1$ and 21 of the treatment period in blood tubes containing $140 \mathrm{IU}$ of sodium heparin (Becton Dickinson and Co., Franklin Lakes, NJ). Plasma was harvested from each sample by centrifugation at $1,500 \times g$ for $20 \mathrm{~min}$ at $4^{\circ} \mathrm{C}$, and plasma aliquots were stored at $-80^{\circ} \mathrm{C}$ while awaiting subsequent analyses for metabolites (AA, BHB, glucose, and fatty acids) and insulin (Garverick et al., 2013; McCarthy et al., 2015). Concentrations of plasma BHB (Sigma-Aldrich, St. Louis, MO), glucose (Sigma-Aldrich), and fatty acids (Wako Diagnostics, Mountain View, CA) were determined using commercially available kits through microplate spectrophotometry (Synergy H1 Multi-Mode Reader; BioTek, Winooski, VT). Concentrations of plasma insulin were determined by double-antibody RIA with 90\% cross-reactivity to bovine insulin (EMD Millipore 
Table 1. Essential amino acid composition of dietary treatments as a proportion of MP predicted by NRC (2001)

\begin{tabular}{|c|c|c|c|c|c|c|c|c|}
\hline \multirow{2}{*}{ Item } & \multicolumn{8}{|c|}{ Experimental diet } \\
\hline & \multicolumn{2}{|c|}{$8 \%$ RUP, g/d } & \multicolumn{2}{|c|}{$6 \%$ RUP, g/d } & \multicolumn{2}{|c|}{$8 \%$ RUP, $\%$ total MP } & \multicolumn{2}{|c|}{$6 \%$ RUP, $\%$ total MP } \\
\hline Total MP & 2,548 & 2,286 & 1,971 & 1,858 & & & & \\
\hline Arg & 123 & 110 & 93.0 & 87.0 & 4.83 & 4.81 & 4.72 & 4.68 \\
\hline $\mathrm{His}$ & 60.0 & 53.5 & 47.0 & 43.0 & 2.35 & 2.34 & 2.38 & 2.31 \\
\hline Lys & 161 & 138 & 131 & 116 & 6.32 & 6.04 & 6.65 & 6.24 \\
\hline Met & 58.0 & 51.0 & 51.0 & 46.0 & 2.28 & 2.23 & 2.59 & 2.48 \\
\hline Phe & 129 & 116 & 100 & 93.0 & 5.06 & 5.07 & 5.07 & 5.01 \\
\hline Thr & 118 & 103 & 94.0 & 86.0 & 4.63 & 4.51 & 4.77 & 4.63 \\
\hline Val & 138 & 123 & 109 & 99.0 & 5.42 & 5.38 & 5.53 & 5.33 \\
\hline $\mathrm{BCAA}^{1}$ & 483 & 433 & 379 & 350 & 19.0 & 18.9 & 19.2 & 18.8 \\
\hline
\end{tabular}

${ }^{1}$ Branched-chain AA $=$ Ile + Leu + Val.

Porcine Insulin RIA; Millipore, St. Charles, MO; Schoenberg and Overton, 2011) using Wizard ${ }^{2}$ Gamma Counter (Perkin Elmer, Waltham, MA). The inter- and intra-assay coefficients of variation were less than $10 \%$ for all blood metabolites and insulin.

Concentrations of plasma free AA (EDTA samples on $\mathrm{d}-1$ and 21 of the study) were measured using liquid chromatography coupled with mass spectrometry and a commercially available kit (Phenomenex EZ:faast, Torrance, CA) as previously described (Meesters et al., 2009; Ubhi et al., 2013; Kassube et al., 2017). Briefly, AA were removed from plasma using solid-phase extraction, derivatization, and liquid-phase extraction. The organic phase was injected into a $250 \times 2.0 \mathrm{~mm}$ HPLC column fitted with a liquid chromatograph-mass spectrometer system (Q Exactive Quadruple-Orbitrap LC-MS; Thermo Scientific, Waltham, MA). The eluents used were composed of $1.0 \mathrm{~m} M$ ammonium formate in water with $10 \mathrm{~m} M$ ammonium formate in methanol. Elution of AA occurred under the gradient of buffers (Ubhi et al., 2013). The flow of eluent was set constant at $0.25 \mathrm{~mL} / \mathrm{min}$ at a column temperature of $35^{\circ} \mathrm{C}$. A 6 -point AA calibration curve was ran before and after running each set of duplicated samples (average $\mathrm{R}^{2}=$ 98.7\%; Ubhi et al., 2013).

\section{Calculations and Statistical Analysis}

Energy balance was calculated using the equation energy balance $=$ net energy intake $-\left[\left(\mathrm{NE}_{\mathrm{M}} \times 1.10\right)+\right.$ $\left.\mathrm{NE}_{\mathrm{L}}\right)$ ]. Net energy intake was calculated using individual dietary $\mathrm{NE}_{\mathrm{L}}$ and observed DMI, as reported previously (Kaufman et al., 2017). Values of $\mathrm{NE}_{\mathrm{M}}$ and $\mathrm{NE}_{\mathrm{L}}$ were calculated from NRC (2001) equations. Requirements for $\mathrm{NE}_{\mathrm{M}}$ were increased by $10 \%$ during the treatment period to address moderate THI (NRC, 2001). Milk protein yield efficiency (MPYE) was calculated as an estimate of MP-AA use efficiency for protein synthesis; thus, MPYE = milk protein yield $(\mathrm{g} / \mathrm{d}) /$ total MP supply $(\mathrm{g} / \mathrm{d})$. Milk protein content was determined on $\mathrm{d}$ $-3,-2$, and -1 relative to treatments and on d 18, 19, and 20 of the treatment period, as previously reported (Kaufman et al., 2017). Data recorded pretreatment were averaged and included in the statistical model for covariance analysis $(\mathrm{d}-1$ for plasma, $\mathrm{d}-3,-2$, and -1 for milk protein yield, MPYE, and MUN, and $d-7$ for energy balance). Data were statistically analyzed as a completely randomized design using the Mixed model procedure in SAS (version 9.4; SAS Institute Inc., Cary, NC). Significance differences were declared at $P \leq 0.05$ and trend to differ at $0.05<P \leq 0.10$. All results are reported as least squares means $( \pm \mathrm{SEM})$. The statistical model was

$$
\begin{aligned}
\mathrm{Y}_{\mathrm{ijk}}=\mu+\mathrm{D}_{\mathrm{i}}+ & \mathrm{U}_{\mathrm{j}}+(\mathrm{D} \times \mathrm{U})_{\mathrm{ij}}+\mathrm{A}(\mathrm{D} \times \mathrm{U})_{\mathrm{ijk}} \\
& +\beta(\chi)_{\mathrm{ijk}}+\mathrm{e}_{\mathrm{ijk}},
\end{aligned}
$$

where $Y_{\mathrm{ijk}}=$ the dependent variable, $\mu=$ the overall mean, $\mathrm{D}_{\mathrm{i}}=$ the fixed effect of the ith RDP treatment $(\mathrm{i}=10$ and $8 \% \mathrm{RDP}), \mathrm{U}_{\mathrm{j}}=$ the fixed effect of the $\mathrm{jth}$ RUP treatment $(\mathrm{j}=8$ and $6 \% \mathrm{RUP}),(\mathrm{D} \times \mathrm{U})_{\mathrm{ij}}=$ the fixed effect of the ith RDP and jth RUP treatment interaction, $\mathrm{A}(\mathrm{D} \times \mathrm{U})_{\mathrm{ijk}}=$ the random effect of the kth animal nested in the ith RDP and jth RUP treatment, $\beta(\chi)_{i j k}=$ the covariate effect, and $e_{i j k}=$ the random error. Significant RDP $\times$ RUP interactions were compared using least significant difference method. Variables of interest were analyzed separately for primiparous and multiparous cows. Two multiparous cows were removed from the study due to unanticipated health concerns (i.e., treatments $8 \mathrm{D}: 8 \mathrm{U}$ and $8 \mathrm{D}: 6 \mathrm{U}$ ). 


\section{RESULTS}

\section{MP and AA Supply}

Treatments were formulated to have AA in equivalent proportions of MP (Table 1). The Lys-to-Met ratio was 3:1, meeting NRC (2001) recommendations. By design, amount of MP and AA supplied in the treatments

A

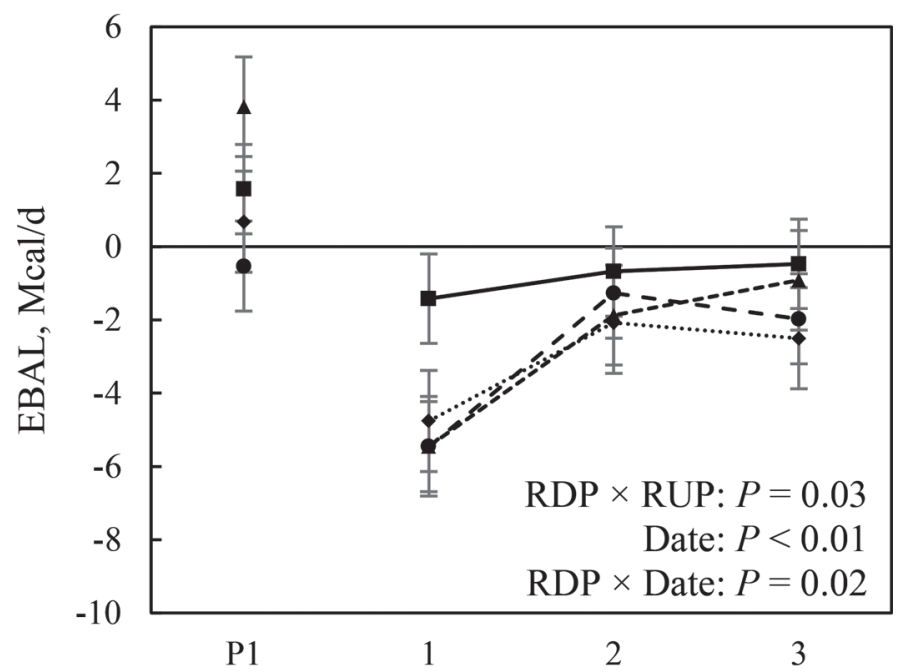

B

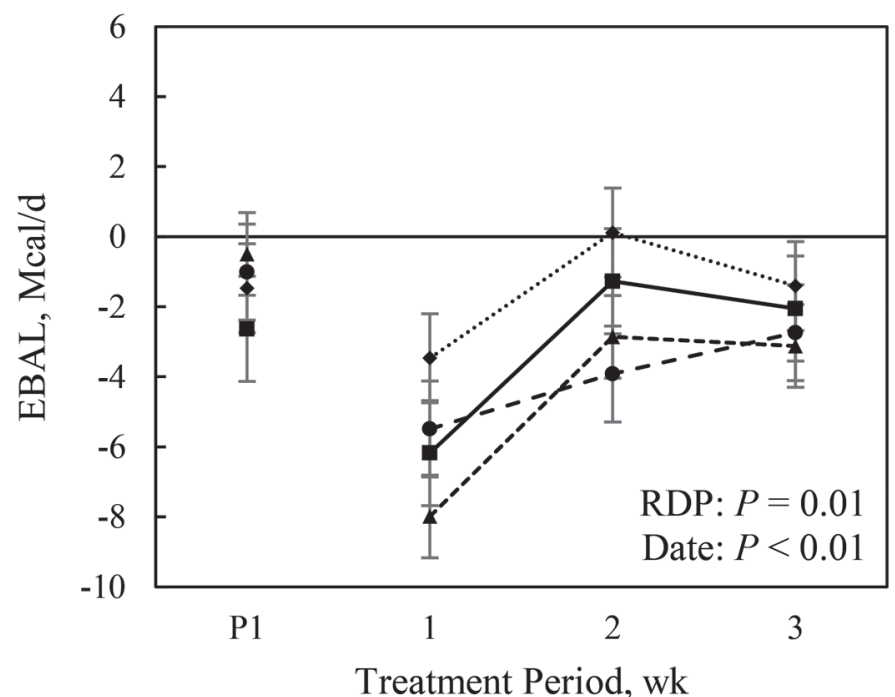

Figure 1. Effect of varying RDP and RUP proportions on energy balance (EBAL). Values are LSM \pm pooled SEM for (A) primiparous and (B) multiparous cows. All cows were fed 10\% RDP, $8 \%$ RUP throughout the week before treatment (P1; mean). Energy balance was calculated as $\mathrm{EBAL}=$ net energy intake $-\left(\mathrm{NE}_{\mathrm{M}}+\mathrm{NE}_{\mathrm{L}}\right)$, where net energy intake is dietary $\mathrm{NE}_{\mathrm{L}} \times \mathrm{DMI} ; \mathrm{NE}_{\mathrm{M}}=[0.8 \times$ metabolic $\mathrm{BW}$ $\left.\left(\mathrm{BW}^{0.75}\right)\right] \times 1.10$; and $\mathrm{NE}_{\mathrm{L}}=[(0.0929 \times$ fat $\%)+(0.0547 \times \mathrm{CP} \%)+$ $(0.0395 \times$ lactose $\%)] \times$ milk yield $($ NRC, 2001$) .10 \%$ RDP, $8 \%$ RUP (solid line, $\mathbf{\square}$ ); $8 \%$ RDP, $8 \%$ RUP (short dashed line, $\mathbf{\Lambda}$ ); 10\% RDP, $6 \%$ RUP (dotted line, $\bullet$ ); $8 \%$ RDP, $6 \%$ RUP (long dashed line, $\bullet$ ). declined with reduction of supplied dietary RDP and RUP. The 10D:8U diet had $262 \mathrm{~g} / \mathrm{d}$ more MP supply compared with the 8D:8U diet, $577 \mathrm{~g} / \mathrm{d}$ more MP supply compared with the 10D:6U diet, and $690 \mathrm{~g} / \mathrm{d}$ more MP supply compared with the 8D:6U diet.

\section{Energy Balance}

Overall, primiparous (Figure 1A) and multiparous (Figure 1B) cows experienced negative energy balance throughout the treatment period. We observed a RDP $\times$ RUP interaction on calculated energy balance in primiparous cows $(P=0.01$; Table 2 ; Figure $1 \mathrm{~A})$, such that reducing RDP from 10 to $8 \%$ decreased energy balance $(3.1 \mathrm{Mcal} / \mathrm{d})$ at $8 \%$ RUP but not at $6 \%$ RUP. Compared with treatment 10D:8U, the $8 \mathrm{D}: 6 \mathrm{U}$ treatment sustained the same energy balance. For multiparous cows, treatment $8 \%$ RDP decreased $(P<0.01)$ energy balance $(2.6 \mathrm{Mcal} / \mathrm{d})$ compared with the $10 \%$ RDP treatment.

\section{Plasma Metabolite and Insulin Concentrations}

Treatments did not affect plasma glucose and fatty acid concentrations in primiparous cows (Table 2). However, reducing RDP from 10 to $8 \%$ decreased $(P=$ $0.03)$ concentrations of insulin $(5.2 \mu \mathrm{U} / \mathrm{mL})$ and BHB $(113 \mu \mathrm{mol} / \mathrm{L})$; reducing RUP from 8 to $6 \%$ decreased $(P<0.01)$ BHB concentration $(241 \mu \mathrm{mol} / \mathrm{L})$.

Treatments did not affect plasma glucose concentration in multiparous cows (Table 2). Compared with $10 \%$ RDP, the $8 \%$ RDP treatment decreased insulin concentration at $6 \%$ RUP $(7.7 \mu \mathrm{U} / \mathrm{mL})$; however, insulin concentration did not change at $8 \%$ RUP $(\mathrm{RDP} \times$ RUP interaction, $P=0.02$ ). Compared with $10 \%$ RDP, the $8 \%$ RDP treatment increased fatty acid concentration at $8 \%$ RUP $(76 \mu \mathrm{Eq} / \mathrm{L})$, but fatty acid concentration did not change for the $6 \%$ RUP treatment $(\mathrm{RDP} \times$ RUP interaction, $P=0.03)$. Compared with $10 \% \mathrm{RDP}$, the $8 \%$ RDP treatment decreased BHB concentration with $8 \%$ RUP $(267 \mu \mathrm{mol} / \mathrm{L})$; however, BHB did not change with $6 \%$ RUP $($ RDP $\times$ RUP interaction, $P<$ $0.01)$.

\section{Milk Protein Synthesis and MUN}

Milk components were previously reported elsewhere (Kaufman et al., 2017). Reducing RUP from 8 to $6 \%$ decreased milk protein yield $(0.08 \mathrm{~kg} / \mathrm{d})$ for primiparous cows $(P=0.04$; Table 2$)$. We found a trend for an interaction such that lowering RUP from 8 to $6 \%$ increased MPYE with 8\% RDP (11.6 percentage units), but MPYE did not change with $10 \%$ RDP (RDP $\times$ 
RUP interaction, $P=0.10)$. Reducing RDP from 10 to $8 \%$ and RUP from 8 to $6 \%$ decreased MUN concentrations (2.7 and $2.9 \mathrm{mg} / \mathrm{dL}$, respectively; $P<0.01$ ).

For multiparous cows, an interaction was present such that lowering RDP from 10 to $8 \%$ decreased milk protein yield with $8 \%$ RUP $(0.07 \mathrm{~kg} / \mathrm{d})$; however, milk protein yield did not change wth $6 \%$ RUP $($ RDP $\times$ RUP interaction, $P=0.03)$. Reducing RUP from 8 to $6 \%$ increased $(P \leq 0.01)$ MPYE $(6.3$ percentage points). Reducing RDP from 10 to $8 \%$ and from RUP 8 to $6 \%$ decreased MUN concentrations (3.7 and $2.5 \mathrm{mg} /$ $\mathrm{dL}$, respectively; $P<0.01)$.

\section{Plasma AA Concentrations}

Treatments did not affect total EAA concentrations in primiparous cows (Table 3 ). We noted a $\mathrm{RDP} \times$ RUP interaction $(P \leq 0.02)$ such that lowering RDP from 10 to $8 \%$ with $6 \%$ RUP decreased total plasma NEAA $(610 \mu M)$ concentrations; however, NEAA concentrations did not change with $8 \%$ RUP.

For multiparous cows, an interaction was present such that lowering RDP from 10 to $8 \%$ increased total circulating EAA concentration with 8\% RUP (389 $\mu M)$; however, EAA concentration did not change with $6 \%$ RUP $($ RDP $\times$ RUP interaction, $P<0.01$; Table 4). Compared with 10\% RDP, the $8 \%$ RDP treatment tended to decrease plasma Arg $(69 \mu M)$ con- centration with $6 \%$ RUP, but Arg concentration did not change with $8 \%$ RUP $($ RDP $\times$ RUP interaction, $P=0.08)$. Compared with $10 \% \mathrm{RDP}$, the $8 \% \mathrm{RDP}$ treatment increased plasma Cit $(17 \mu M)$ and Orn $(27$ $\mu M$ ) concentrations with the $8 \%$ RUP treatment, but concentrations decreased with 6\% RUP (45 and $25 \mu \mathrm{M}$, respectively; RDP $\times$ RUP interaction, $P<0.01)$. Compared with $10 \%$ RDP, the $8 \%$ RDP treatment increased plasma 3-methylhistidine concentration with $8 \%$ RUP $(3.0 \mu \mathrm{M})$, but 3-methylhistidine concentration did not change with $6 \%$ RUP $($ RDP $\times$ RUP interaction, $P=$ 0.01 ). Reducing RUP from 8 to $6 \%$ decreased plasma 3-methylhistidine concentration at $8 \% \operatorname{RDP}(3.9 \mu M)$ but not with $10 \%$ RDP.

\section{DISCUSSION}

The objective of our study was to assess the effect of reducing RDP and RUP on plasma metabolites indicative of AA and energy metabolism in lactating dairy cows. Compared with the 10D:8U diet, reduction of RDP and RUP lowered circulating levels of insulin and $\mathrm{BHB}$, and this effect was more prominent in multiparous cows. In agreement with these results, earlylactation dairy cows fed a $15 \% \mathrm{CP}$ diet had reduced plasma insulin concentrations compared with cows fed an $18 \% \mathrm{CP}$ diet (Bach et al., 2000). Our results revealed an improvement in efficiency of AA utilization

Table 2. Milk protein yield and efficiency, MUN, plasma concentrations of metabolites and insulin, and energy balance of lactating Holstein cows fed varying amounts of RDP and RUP in warm climates (LSM \pm SEM)

\begin{tabular}{|c|c|c|c|c|c|c|c|c|}
\hline \multirow[b]{3}{*}{ Item } & \multicolumn{4}{|c|}{ Experimental diet } & \multirow[b]{3}{*}{ SEM } & \multirow{2}{*}{\multicolumn{3}{|c|}{ Effect ( $P$-value $)$}} \\
\hline & \multicolumn{2}{|c|}{$8 \%$ RUP } & \multicolumn{2}{|c|}{$6 \%$ RUP } & & & & \\
\hline & $10 \% \mathrm{RDP}$ & $8 \% \mathrm{RDP}$ & $10 \% \mathrm{RDP}$ & $8 \% \mathrm{RDP}$ & & $\mathrm{RDP}(\mathrm{D})$ & RUP (U) & $\mathrm{D} \times \mathrm{U}$ \\
\hline Primiparous, n & 5 & 4 & 4 & 5 & & & & \\
\hline $\mathrm{EBAL}^{1} \mathrm{Mcal} / \mathrm{d}$ & $0.05^{\mathrm{a}}$ & $-3.05^{\mathrm{b}}$ & $-3.50^{\mathrm{b}}$ & $-1.99^{\mathrm{ab}}$ & 0.99 & 0.36 & 0.18 & 0.01 \\
\hline Milk protein yield, $\mathrm{kg} / \mathrm{d}$ & 1.01 & 0.98 & 0.89 & 0.94 & 0.04 & 0.80 & 0.04 & 0.25 \\
\hline $\mathrm{MPYE}^{2} \%$ & 40.1 & 39.0 & 41.2 & 50.6 & 3.70 & 0.20 & 0.05 & 0.10 \\
\hline MUN, mg/dL & 11.2 & 8.34 & 8.19 & 5.61 & 0.52 & $<0.01$ & $<0.01$ & 0.82 \\
\hline Glucose, $\mathrm{mmol} / \mathrm{L}$ & 3.01 & 3.01 & 2.81 & 3.16 & 0.11 & 0.11 & 0.81 & 0.11 \\
\hline Insulin, $\mu \mathrm{U} / \mathrm{mL}$ & 23.4 & 16.8 & 18.4 & 14.6 & 2.22 & 0.03 & 0.12 & 0.56 \\
\hline Fatty acids, $\mu \mathrm{Eq} / \mathrm{L}$ & 117 & 119 & 133 & 174 & 14.9 & 0.19 & 0.06 & 0.44 \\
\hline $\mathrm{BHB}, \mu \mathrm{mol} / \mathrm{L}$ & 662 & 559 & 431 & 308 & 49.5 & 0.03 & $<0.01$ & 0.86 \\
\hline Multiparous, $\mathrm{n}$ & 7 & 7 & 8 & 6 & & & & \\
\hline EBAL, Mcal/d & -2.08 & -5.12 & -2.23 & -4.29 & 0.96 & $<0.01$ & 0.68 & 0.55 \\
\hline Milk protein yield, $\mathrm{kg} / \mathrm{d}$ & $1.12^{\mathrm{a}}$ & $1.05^{\mathrm{b}}$ & $1.01^{\mathrm{b}}$ & $1.06^{\mathrm{ab}}$ & 0.02 & 0.61 & 0.04 & 0.03 \\
\hline MPYE, \% & 45.3 & 44.2 & 50.8 & 57.3 & 3.32 & 0.34 & $<0.01$ & 0.17 \\
\hline MUN, mg/dL & 11.7 & 7.98 & 9.17 & 5.46 & 0.54 & $<0.01$ & $<0.01$ & 0.98 \\
\hline Glucose, $\mathrm{mmol} / \mathrm{L}$ & 3.02 & 3.16 & 3.05 & 3.16 & 0.09 & 0.21 & 0.90 & 0.90 \\
\hline Insulin, $\mu \mathrm{U} / \mathrm{mL}$ & $22.8^{\mathrm{a}}$ & $19.8^{\mathrm{a}}$ & $19.7^{\mathrm{a}}$ & $12.0^{\mathrm{b}}$ & 2.12 & 0.02 & 0.28 & 0.02 \\
\hline Fatty acids, $\mu \mathrm{Eq} / \mathrm{L}$ & $123^{\mathrm{b}}$ & $199^{\mathrm{a}}$ & $206^{\mathrm{a}}$ & $175^{\mathrm{a}}$ & 22.9 & 0.33 & 0.03 & 0.03 \\
\hline $\mathrm{BHB}, \mu \mathrm{mol} / \mathrm{L}$ & $662^{\mathrm{a}}$ & $395^{\mathrm{b}}$ & $342^{\mathrm{b}}$ & $460^{\mathrm{b}}$ & 47.8 & 0.13 & 0.01 & $<0.01$ \\
\hline
\end{tabular}

\footnotetext{
${ }^{a, b}$ Values within a row with differing superscripts denote RDP $\times$ RUP interactions $(P \leq 0.05)$.

${ }^{1}$ Energy balance $=$ net energy intake $\left.-\left[\left(\mathrm{NE}_{\mathrm{M}} \times 1.10\right)+\mathrm{NE}_{\mathrm{L}}\right)\right]$.

${ }^{2}$ Milk protein yield efficiency $=$ milk protein yield $(\mathrm{g} / \mathrm{d}) /$ total MP supply $(\mathrm{g} / \mathrm{d})$ from Table 1.
} 
for milk protein synthesis. The current results indicate that reduction of RDP and RUP promoted availability and utilization of AA, fatty acids, and BHB in support of milk protein synthesis in mid-lactation cows exposed to heat stress.

\section{Plasma Concentrations of Metabolites and Insulin}

Primiparous cows showed similar insulin reductions compared with that found in multiparous cows, although the RDP by RUP interaction was not significant. Multiparous cows showed a dramatic decline of circulating insulin when reducing RDP in the low-RUP diet. This suggests that the reduction of RDP and RUP lowered the stimulatory effect of circulating EAA on insulin secretion (Kuhara et al., 1991). Insulin, a potent lipolytic inhibitor, promotes lipogenesis by increasing fatty acid esterification (Vernon, 1992). Moreover, insulin promotes whole-body protein synthesis and glucose utilization in insulin-sensitive tissues (e.g., adipose and skeletal muscle; Bauman and Elliot, 1983; Sanz Fernandez et al., 2015). Although lipolysis and lipogenesis were not determined in the current study, the $10 \mathrm{D}: 8 \mathrm{U}$ diet had greater insulin concentrations that resulted in a $\sim 30 \%$ decrease in circulating fatty acid levels compared with lower-RDP and -RUP diets in multiparous cows. Increased insulin likely inhibited lipolysis, causing a reduction in plasma fatty acid concentrations even though cows were in negative energy balance. Furthermore, insulin inhibits complete oxidation of fatty acids, which increases production of ketone bodies (Wathes et al., 2007). In the present study, greater insulin secretion observed in the 10D:8U diet may have inhibited complete oxidation of fatty acids because concentrations of BHB increased by $44 \%$ compared with the $8 \mathrm{D}: 6 \mathrm{U}$ diet in multiparous cows. In primiparous cows, the reduction of RDP reduced plasma insulin concentration, and the reduction of RDP and RUP reduced BHB plasma concentrations. In comparison with previous work in late-lactating primiparous cows, supplementation with $300 \mathrm{~g} / \mathrm{d}$ of formaldehyde-treated casein, to limit rumen degradability and increase EAA supply in MP, showed a $40 \%$ increase in plasma insulin concentrations compared with nonsupplemented animals (Hunter and Magner, 1988). In the current study, cows fed low RDP and RUP had negative MP balance and the lowest

Table 3. Plasma AA concentrations $(\mu M)$ of lactating primiparous Holstein cows fed varying amounts of RDP and RUP in warm climates $(\mathrm{LSM} \pm \mathrm{SEM})$

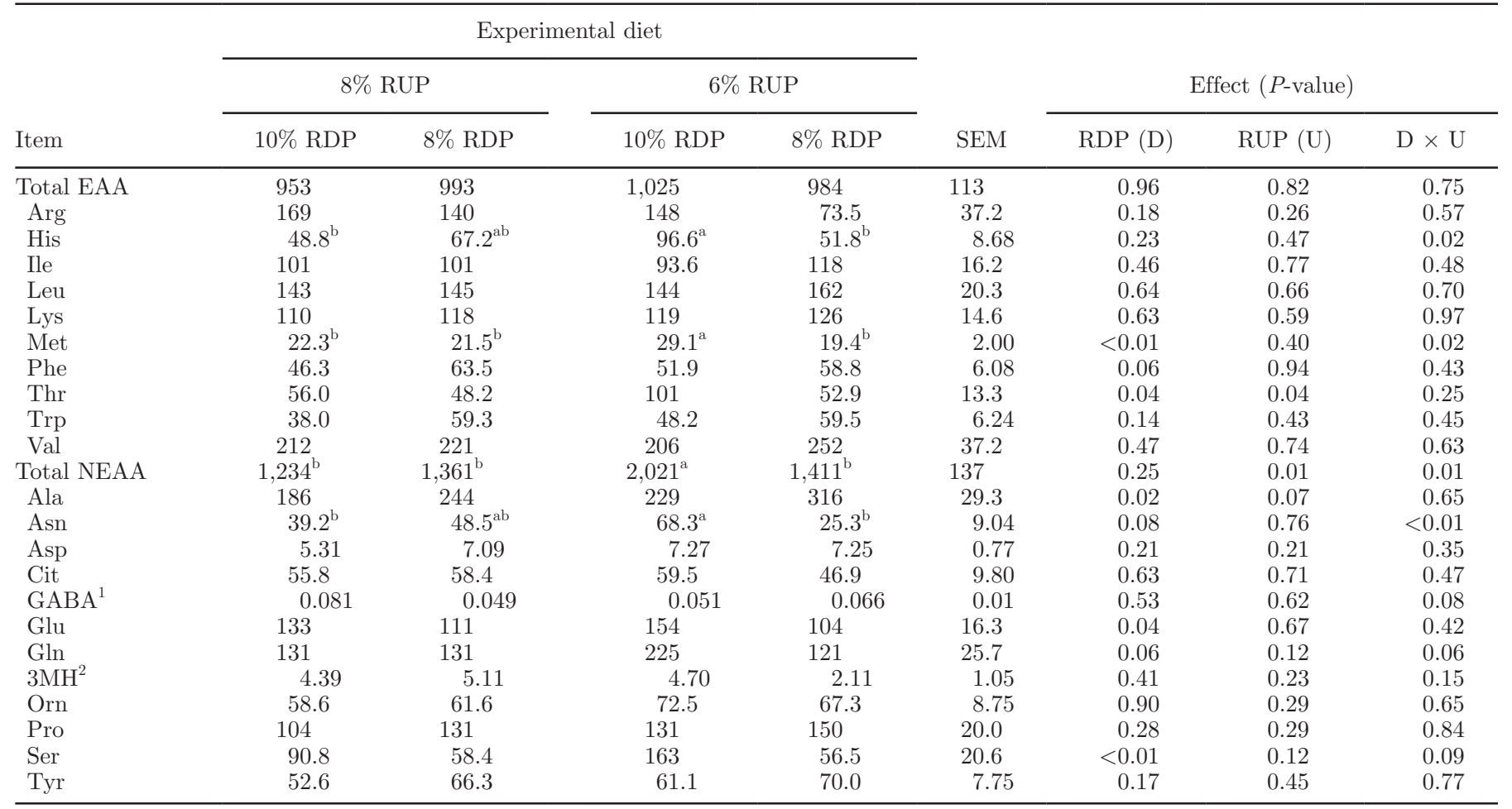

\footnotetext{
${ }^{\mathrm{a}, \mathrm{b}}$ Values within a row with differing superscripts denote RDP $\times$ RUP interactions $(P \leq 0.05)$

${ }^{1} \gamma$-Aminobutyric acid.

${ }^{2} 3$-Methylhistidine.
} 
circulating insulin levels, which most likely promoted mobilization and oxidation of fatty acids. In conclusion, multiparous cows responded to lower RDP and RUP diets by reducing plasma insulin concentrations and supporting fatty acid mobilization and utilization.

\section{Plasma Concentrations of $A A$}

In multiparous cows, diet 8D:6U showed a $22 \%$ greater concentration of total EAA compared with the 10D:8U diet. Plasma concentrations of AA represent the net result between the supply of MP and the utilization of AA (i.e., protein synthesis and AA catabolism; Meijer et al., 1995). In the present study, MPYE was $21 \%$ greater in diets with $6 \%$ RUP compared with $8 \%$ RUP and numerically greatest in the $8 \mathrm{D}: 6 \mathrm{U}$ diet by $27 \%$ compared with the $10 \mathrm{D}: 8 \mathrm{U}$ diet. Diet 10D:8U increased circulating insulin levels, an anabolic signal that likely increased whole-body protein synthesis (e.g., skeletal muscle; Bauman and Elliot, 1983), which in turn increases removal of circulating AA and caused a decline in AA concentrations. The lower circulating AA levels observed in the 10D:8U diet could be the response to elevated insulin concentrations that increase AA removal and utilization in peripheral tissues (Ahmed et al., 1983; Prior and Smith, 1983). This is because milk protein yield did not differ and MPYE increased from 45.3 to $57.3 \%$ in $8 \mathrm{D}: 6 \mathrm{U}$ compared with $10 \mathrm{D}: 8 \mathrm{U}$ cows. Furthermore, reduction of RDP and RUP reduced MP supply and, in turn, reduced plasma insulin concentrations and the use of circulating AA on insulin-sensitive tissues. Therefore, the response to reductions of RDP and RUP observed in the 8D:6U treatment likely limited the utilization of AA in peripheral tissue by lowering substrate availability (e.g., substrate-level regulation of nutrient utilization; Kriel et al., 1992) while sustaining milk protein synthesis.

\section{Plasma Biomarker Concentrations of Skeletal Muscle Catabolism}

The 10D:8U and 8D:6U diets promoted lower circulating 3-methylhistidine levels compared with the $8 \mathrm{D}: 8 \mathrm{U}$ diet in multiparous cows. Circulating 3-methylhistidine levels are used as a biomarker of skeletal muscle degradation and muscle protein turnover in

Table 4. Plasma AA concentrations $(\mu M)$ of lactating multiparous Holstein cows fed varying amounts of RDP and RUP in warm climates $(\mathrm{LSM} \pm \mathrm{SEM})$

\begin{tabular}{|c|c|c|c|c|c|c|c|c|}
\hline \multirow[b]{2}{*}{ Item } & \multicolumn{4}{|c|}{ Experimental diet } & \multirow[b]{2}{*}{ SEM } & \multicolumn{3}{|c|}{ Effect ( $P$-value) } \\
\hline & $10 \% \mathrm{RDP}$ & $8 \% \mathrm{RDP}$ & $10 \% \mathrm{RDP}$ & $8 \% \mathrm{RDP}$ & & $\mathrm{RDP}(\mathrm{D})$ & RUP (U) & $\mathrm{D} \times \mathrm{U}$ \\
\hline Total EAA & $907^{\mathrm{b}}$ & $1,296^{\mathrm{a}}$ & $1,245^{\mathrm{a}}$ & $1,110^{\mathrm{a}}$ & 87.6 & 0.50 & 0.03 & $<0.01$ \\
\hline Arg & 132 & 132 & 182 & 113 & 17.7 & 0.07 & 0.40 & 0.08 \\
\hline His & $49.2^{\mathrm{b}}$ & $98.2^{\mathrm{a}}$ & $102^{\mathrm{a}}$ & $86.7^{\mathrm{a}}$ & 13.3 & 0.10 & 0.12 & 0.05 \\
\hline Lys & $106^{\mathrm{b}}$ & $162^{\mathrm{a}}$ & $160^{\mathrm{a}}$ & $138^{\mathrm{a}}$ & 9.58 & 0.10 & 0.15 & $<0.01$ \\
\hline Met & 20.0 & 24.6 & 29.2 & 28.5 & 2.25 & 0.42 & $<0.01$ & 0.27 \\
\hline Phe & $49.8^{\mathrm{b}}$ & $77.8^{\mathrm{a}}$ & $77.6^{\mathrm{a}}$ & $65.7^{\mathrm{a}}$ & 5.03 & 0.13 & 0.14 & $<0.01$ \\
\hline Thr & 95.7 & 188 & 148 & 124 & 32.7 & 0.64 & 0.96 & 0.07 \\
\hline $\operatorname{Trp}$ & $42.3^{\mathrm{b}}$ & $69.5^{\mathrm{a}}$ & $77.4^{\mathrm{a}}$ & $69.5^{\mathrm{a}}$ & 4.08 & 0.03 & $<0.01$ & $<0.01$ \\
\hline Val & 188 & 237 & 196 & 219 & 28.1 & 0.23 & 0.85 & 0.66 \\
\hline Total NEAA & 1,522 & 2,004 & 1,838 & 1,643 & 245 & 0.79 & 0.66 & 0.13 \\
\hline Glu & 125 & 114 & 160 & 130 & 11.9 & 0.11 & 0.05 & 0.43 \\
\hline Gln & $120^{\mathrm{c}}$ & $184^{\mathrm{ab}}$ & $237^{\mathrm{a}}$ & $148^{\mathrm{bc}}$ & 19.8 & 0.57 & 0.06 & $<0.01$ \\
\hline $3 \mathrm{MH}^{2}$ & $3.86^{\mathrm{b}}$ & $6.85^{\mathrm{a}}$ & $6.61^{\mathrm{ab}}$ & $2.97^{\mathrm{b}}$ & 1.18 & 0.80 & 0.65 & 0.01 \\
\hline Orn & $51.7^{\mathrm{c}}$ & $78.7^{\mathrm{ab}}$ & $97.6^{\mathrm{a}}$ & $72.5^{\mathrm{b}}$ & 5.55 & 0.87 & $<0.01$ & $<0.01$ \\
\hline Pro & 103 & 136 & 131 & 145 & 14.3 & 0.13 & 0.23 & 0.52 \\
\hline Ser & $82.3^{\mathrm{c}}$ & $137^{\mathrm{ab}}$ & $179^{\mathrm{a}}$ & $80.0^{\mathrm{bc}}$ & 20.5 & 0.32 & 0.37 & $<0.01$ \\
\hline Tyr & $56.9^{\mathrm{b}}$ & $86.5^{\mathrm{a}}$ & $84.5^{\mathrm{a}}$ & $80.9^{\mathrm{a}}$ & 6.60 & 0.07 & 0.12 & 0.02 \\
\hline
\end{tabular}

\footnotetext{
${ }^{\mathrm{a}-\mathrm{c}}$ Values within a row with differing superscripts denote RDP $\times$ RUP interactions $(P \leq 0.05)$.

${ }^{1} \gamma$-Aminobutyric acid.

${ }^{2} 3$-Methylhistidine.
} 
farm (Blum et al., 1985; Kamiya et al., 2006b) and laboratory animals (Young et al., 1972; Thompson et al., 1996) because methylation of His residues is a posttranslational modification of myofibrillar actin and fast-twitch myosin after synthesis. Thus, an increase in plasma concentrations of 3-methylhistidine denotes an increase in protein degradation unique for skeletal muscle. An increase in muscle proteolysis may be initiated to oxidize C-skeletons from AA oxidation to support increased energy requirements (NRC, 2001), which is consistent with the observation in heat-stressed cows (Kamiya et al., 2006a; Lamp et al., 2015) and poultry (Yunianto et al., 1997). However, muscle breakdown likely provided AA to sustain gluconeogenesis (Rhoads et al., 2011). Plasma concentrations of 3-methylhistidine were increased when cows were fed a limited energy supply in the diet (Ndibualonji et al., 1997). The 10D:8U diet that elicited an increase on MP supply and circulating insulin may have increased synthesis of skeletal muscle and prevented muscle degradation and higher 3-methylhistidine concentrations (Vandehaar et al., 1999). However, the 8D:6U diet also reduced 3-methylhistidine concentrations, which indicates a reduction of muscle protein degradation and turnover. Reducing circulating AA increases their clearance in the mammary glands while reducing whole-body catabolism of proteins and AA (Bequette et al., 2000; Rius et al., 2010). Thus, in this study, reduction of RDP and RUP promoted the use of circulating AA in the udder and sustained milk protein synthesis while limiting AA mobilization from skeletal muscle.

\section{Plasma Concentrations of Intermediates in the Synthesis of Urea}

Reduction of RDP at $6 \%$ RUP decreased plasma Cit (46\%) and Orn (26\%) and tended to decrease Arg $(38 \%)$ in multiparous cows. Relative to $10 \mathrm{D}: 8 \mathrm{U}$, the 8D:6U diet had similar Cit but greater Orn concentrations. These results suggest a reduction on AA oxidation in splanchnic tissues and less hepatic conversion of ammonia to urea (Hanigan et al., 1998; Barr et al., 2003; Doepel and Lapierre, 2010). In the 8D:6U diet, an increase in Orn concentrations in relation to Cit concentrations $(19 \mu M)$ is indicative of a slowdown of urea synthesis (Barr et al., 2003). In comparison, the 10D:8U diet resulted in a lower concentration of Orn relative to Cit $(-1.7 \mu M)$, indicating that synthesis of urea was likely not reduced. The urea synthesis pathway is controlled by the rate-limiting enzyme carbamoyl phosphate synthetase that makes carbamoyl phosphate, which is then condensed with Orn to produce Cit. The increased concentration of Orn observed in cows fed diet 8D:6U, compared with diet 10D:8U, could be the result of a lower provision of ammonium ions as a result of a decline in MP supply (Raggio et al., 2004). Compared with the 10D:8U diet, the $8 \mathrm{D}: 6 \mathrm{U}$ diet might have reduced hepatic urea synthesis as indicated from low concentrations of MUN. In agreement with current results, pigs fed 11 to $12 \% \mathrm{CP}$ diets compared with $16 \%$ $\mathrm{CP}$ had reduced Arg and Orn concentrations, which were associated with-reduced urea synthesis (Figueroa et al., 2003). Notably, primiparous cows responded with no change in Cit and Orn concentrations; therefore, reducing RDP and RUP in the diet of multiparous cows exposed to thermal stress limited the synthesis of urea through reduced AA supply and condensation of Orn with carbamoyl phosphate to produce Cit.

\section{CONCLUSIONS}

Primiparous and multiparous cows showed metabolic and hormonal changes in response to a reduction of RDP and RUP. Multiparous cows fed a low-RDP and low-RUP diet had reduced circulating insulin levels, which supported the utilization of nutrients in the mammary glands. Feeding lactating dairy cows greater RDP and RUP proportions prompted elevated circulating insulin levels and limited BHB utilization. Alternatively, reduction of RDP and RUP decreased urea nitrogen output in milk and skeletal muscle proteolysis while increasing the efficiency of milk protein synthesis. Overall, reducing RDP and RUP improved the metabolic status of heat-stressed multiparous cows and increased the utilization of AA.

\section{ACKNOWLEDGMENTS}

The authors acknowledge the funding for this project provided by the Institute of Agriculture at the University of Tennessee. The authors acknowledge the assistance of A. Saxton (University of Tennessee-Knoxville) and East Tennessee AgResearch and Education Center Little River Animal and Environmental Unit staff. The authors thank the assistance of S. R. Campagna, H. F. Castro, and J. B. Powers with the University of Tennessee-Knoxville.

\section{REFERENCES}

Ahmed, B. M., W. G. Bergen, and N. K. Ames. 1983. Effect of nutritional state and insulin on hind-limb amino acid metabolism in steers. J. Nutr. 113:1529-1543.

Bach, A., G. B. Huntington, S. Calsamiglia, and M. D. Stern. 2000. Nitrogen metabolism of early lactation cows fed diets with two different levels of protein and different amino acid profiles. J. Dairy Sci. 83:2585-2595. https://doi.org/10.3168/jds.S0022-0302(00)75152 $-6$. 
Barr, F. E., H. Beverley, K. VanHook, E. Cermak, K. Christian, D Drinkwater, K. Dyer, N. T. Raggio, J. H. Moore, and B. Christman. 2003. Effect of cardiopulmonary bypass on urea cycle intermediates and nitric oxide levels after congenital heart surgery. J. Pediatr. 142:26-30. https://doi.org/10.1067/mpd.2003.mpd0311.

Bauman, D. E., and J. M. Elliot. 1983. Control of nutrient partitioning in lactating ruminants. Pages 437-462 in Biochemistry of Lactation. T. B. Mepham, ed. Elsevier, Amsterdam, the Netherlands.

Bell, A. W. 1995. Regulation of organic nutrient metabolism during transition from late pregnancy to early lactation. J. Anim. Sci. 73:2804-2819. https://doi.org/10.2527/1995.7392804x.

Bequette, B. J., M. D. Hanigan, A. G. Calder, C. K. Reynolds, G. E. Lobley, and J. C. MacRae. 2000. Amino acid exchange by the mammary gland of lactating goats when histidine limits milk production. J. Dairy Sci. 83:765-775. https://doi.org/10.3168/jds .S0022-0302(00)74939-3.

Blum, J. W., T. Reding, F. Jans, M. Wanner, M. Zemp, and K. Bachmann. 1985. Variations of 3-methylhistidine in blood of dairy cows. J. Dairy Sci. 68:2580-2587. https://doi.org/10.3168/jds.S0022 $-0302(85) 81140-1$.

Doepel, L., and H. Lapierre. 2010. Changes in production and mammary metabolism of dairy cows in response to essential and nonessential amino acid infusions. J. Dairy Sci. 93:3264-3274. https:// doi.org/10.3168/jds.2009-3033.

Figueroa, J. L., A. J. Lewis, P. S. Miller, R. L. Fischer, and R. M. Diedrichsen. 2003. Growth, carcass traits, and plasma amino acid concentrations of gilts fed low-protein diets supplemented with amino acids including histidine, isoleucine, and valine. J. Anim. Sci. 81:1529-1537. https://doi.org/10.2527/2003.8161529x.

Garverick, H. A., M. N. Harris, R. Vogel-Bluel, J. D. Sampson, J. Bader, W. R. Lamberson, J. N. Spain, M. C. Lucy, and R. S. Youngquist. 2013. Concentrations of nonesterified fatty acids and glucose in blood of periparturient dairy cows are indicative of pregnancy success at first insemination. J. Dairy Sci. 96:181-188. https://doi.org/10.3168/jds.2012-5619.

Hanigan, M. D., J. P. Cant, D. C. Weakley, and J. L. Beckett. 1998. An evaluation of postabsorptive protein and amino acid metabolism in the lactating dairy cow. J. Dairy Sci. 81:3385-3401. https://doi .org/10.3168/jds.S0022-0302(98)75903-X.

Hunter, R. A., and T. Magner. 1988. The effect of supplements of formaldehyde-treated casein on the partitioning of nutrients between cow and calf in lactating Bos indicus x Bos taurus heifers fed a roughage diet. Aust. J. Agric. Res. 39:1151-1162. https://doi .org/10.1071/AR9881151.

Kamiya, M. Y. Kamiya, M. Tanaka, T. Oki, Y. Nishiba, and S. Shioya. 2006a. Effects of high ambient temperature and restricted feed intake on urinary and plasma 3-methylhistidine in lactating Holstein cows. Anim. Sci. J. 77:201-207. https://doi.org/10.1111/ j.1740-0929.2006.00338.x.

Kamiya, M., Y. Kamiya, M. Tanaka, and S. Shioya. 2006b. Milk protein production and plasma 3-methylhistidine concentration in lactating Holstein cows exposed to high ambient temperatures. Asian-australas. J. Anim. Sci. 19:1159-1163. /https://doi.org/10 .5713 /ajas.2006.1159.

Kassube, K. R., J. D. Kaufman, K. G. Pohler, J. W. McFadden, and A. G. Rius. 2017. Jugular-infused methionine, lysine and branchedchain amino acids does not improve milk production in Holstein cows experiencing heat stress. Animal https://doi.org/10.1017/ S1751731117001057.

Kaufman, J. D., K. R. Kassube, and A. G. Ríus. 2017. Lowering rumen-degradable protein maintained energy-corrected milk yield and improved nitrogen-use efficiency in multiparous lactating dairy cows exposed to heat stress. J. Dairy Sci. 100:8132-8145. https://doi.org/10.3168/jds.2017-13026.

Kriel, G. V., M. A. Lomax, and M. J. Bryant. 1992. Effect of manipulation of the efficiency of nitrogen retention by diet on plasma insulin-like growth factor-1 (IGF-I) concentration. Proc. Nutr. Soc. 51:45A.

Kuhara, T., S. Ikeda, A. Ohneda, and Y. Sasaki. 1991. Effects of intravenous infusion of 17 amino acids on the secretion of $\mathrm{GH}$, glucagon, and insulin in sheep. Am. J. Physiol. 260:E21-E26.
Lamp, O., M. Derno, W. Otten, M. Mielenz, G. Nürnberg, and B. Kuhla. 2015. Metabolic heat stress adaption in transition cows: Differences in macronutrient oxidation between late-gestating and early-lactating German Holstein dairy cows. PLoS One 10:e0125264. https://doi.org/10.1371/journal.pone.0125264.

Manns, J. G., and J. M. Boda. 1967. Insulin release by acetate, propionate, butyrate, and glucose in lambs and adult sheep. Am. J. Physiol. 212:747-755.

McCarthy, M. M., S. Mann, D. V. Nydam, T. R. Overton, and J. A. A. McArt. 2015. Short communication: Concentrations of nonesterified fatty acids and $\beta$-hydroxybutyrate in dairy cows are not well correlated during the transition period. J. Dairy Sci. 98:6284-6290. https://doi.org/10.3168/jds.2015-9446.

Meesters, R. J. W., R. R. Wolfe, and N. E. P. Deutz. 2009. Application of liquid chromatography-tandem mass spectrometry (LC-MS/ MS) for the analysis of stable isotope enrichments of phenylalanine and tyrosine. J. Chromatogr. B Analyt. Technol. Biomed. Life Sci. 877:43-49. https://doi.org/10.1016/j.jchromb.2008.11.018.

Meijer, G. A. L., J. Van Der Meulen, J. G. M. Bakker, C. J. Van Der Koelen, and A. M. Van Vuuren. 1995. Free amino acids in plasma and muscle of high yielding dairy cows in early lactation. J. Dairy Sci. 78:1131-1141. https://doi.org/10.3168/jds.S0022 -0302(95)76730-3.

Ndibualonji, B. B., D. Dehareng, F. Beckers, C. Van Eenaeme, and J. M. Godeau. 1997. Continuous profiles and within-day variations of metabolites and hormones in cows fed diets varying in alimentary supplies before short-term feed deprivation. J. Anim. Sci. 75:32623277. https://doi.org/10.2527/1997.75123262x.

NRC. 2001. Nutrient Requirements of Dairy Cattle. 7th rev. ed. Natl. Acad. Press, Washington, DC.

Prior, R. L., and S. B. Smith. 1983. Role of insulin in regulating amino acid metabolism in normal and alloxan-diabetic cattle. J. Nutr. 113:1016-1031.

Raggio, G., D. Pacheco, R. Berthiaume, G. E. Lobley, D. Pellerin, G. Allard, P. Dubreuil, and H. Lapierre. 2004. Effect of level of metabolizable protein on splanchnic flux of amino acids in lactating dairy cows. J. Dairy Sci. 87:3461-3472. /https://doi.org/10.3168/ jds.S0022-0302(04)73481-5.

Randle, P. J. 1998. Regulatory interactions between lipids and carbohydrates: The glucose fatty acid cycle after 35 years. Diabetes Metab. Rev. 14:268-283.

Rhoads, M. L., R. P. Rhoads, M. J. VanBaale, R. J. Collier, S. R. Sanders, W. J. Weber, B. A. Crooker, and L. H. Baumgard. 2009. Effects of heat stress and plane of nutrition on lactating Holstein cows: I. Production, metabolism, and aspects of circulating somatotropin. J. Dairy Sci. 92:1986-1997. https://doi.org/10.3168/ jds.2008-1641.

Rhoads, R. P., A. J. La Noce, J. B. Wheelock, and L. H. Baumgard. 2011. Short communication: Alterations in expression of gluconeogenic genes during heat stress and exogenous bovine somatotropin administration. J. Dairy Sci. 94:1917-1921. https://doi.org/10 $.3168 /$ jds.2010-3722.

Rius, A. G., J. A. D. R. N. Appuhamy, J. Cyriac, D. Kirovski, O. Becvar, J. Escobar, M. L. McGilliard, B. J. Bequette, R. M. Akers, and M. D. Hanigan. 2010. Regulation of protein synthesis in mammary glands of lactating dairy cows by starch and amino acids. J. Dairy Sci. 93:3114-3127. https://doi.org/10.3168/jds.2009-2743.

Sanz Fernandez, M. V., S. K. Stoakes, M. Abuajamieh, J. T. Seibert, J. S. Johnson, E. A. Horst, R. P. Rhoads, and L. H. Baumgard. 2015. Heat stress increases insulin sensitivity in pigs. Physiol. Rep. 3:e12478 https://doi.org/10.14814/phy2.12478.

Schoenberg, K. M., and T. R. Overton. 2011. Effects of plane of nutrition and 2,4-thiazolidinedione on insulin responses and adipose tissue gene expression in dairy cattle during late gestation. J. Dairy Sci. 94:6021-6035. https://doi.org/10.3168/jds.2011-4533.

Thompson, M. G., R. M. Palmer, A. Thom, S. C. Mackie, K. S. Morrison, and C. I. Harris. 1996. Measurement of protein degradation by release of labelled 3-methylhistidine from skeletal muscle and non-muscle cells. J. Cell. Physiol. 166:506-511. https://doi.org/10 .1002/(SICI)1097-4652(199603)166:3<506::AID-JCP5>3.0.CO;2$\mathrm{T}$. 
Ubhi, B. K., P. W. Davenport, M. Welch, J. Riley, J. L. Griffin, and S. C. Connor. 2013. Analysis of chloroformate-derivatised amino acids, dipeptides and polyamines by LC-MS/MS. J. Chromatogr. B Analyt. Technol. Biomed. Life Sci. 934:79-88. https://doi.org/ 10.1016/j.jchromb.2013.06.026.

Vandehaar, M. J., G. Yousif, B. K. Sharma, T. H. Herdt, R. S. Emery, M. S. Allen, and J. S. Liesman. 1999. Effect of energy and protein density of prepartum diets on fat and protein metabolism of dairy cattle in the periparturient period. J. Dairy Sci. 82:1282-1295. https://doi.org/10.3168/jds.S0022-0302(99)75351-8.

Vernon, R. G. 1992. Effects of diet on lipolysis and its regulation. Proc. Nutr. Soc. 51:397-408. https://doi.org/10.1079/PNS19920053.

Wathes, D. C., Z. Cheng, N. Bourne, V. J. Taylor, M. P. Coffey, and S. Brotherstone. 2007. Differences between primiparous and multiparous dairy cows in the inter-relationships between metabolic traits, milk yield and body condition score in the periparturient period. Domest. Anim. Endocrinol. 33:203-225. https://doi.org/10.1016/j .domaniend.2006.05.004.
Wheelock, J. B., R. P. Rhoads, M. J. VanBaale, S. R. Sanders, and L. H. Baumgard. 2010. Effects of heat stress on energetic metabolism in lactating Holstein cows. J. Dairy Sci. 93:644-655. https://doi .org/10.3168/jds.2009-2295.

Wiley, J. S., M. K. Petersen, R. P. Ansotegui, and R. A. Bellows. 1991. Production from first-calf beef heifers fed a maintenance or low level of prepartum nutrition and ruminally undegradable or degradable protein postpartum. J. Anim. Sci. 69:4279-4293. https:// doi.org/10.2527/1991.69114279x.

Young, V. R., S. D. Alexis, B. S. Baliga, H. N. Munro, and W. Muecke. 1972. Metabolism of administered 3-methylhistidine. Lack of muscle transfer ribonucleic acid charging and quantative excretion as 3-methylhistidine and its N-acetyl derivative. J. Biol. Chem. 247:3592-3600

Yunianto, V. D., K. Hayashit, S. Kaiwda, A. Ohtsuka, and Y. Tomita. 1997. Effect of environmental temperature on muscle protein turnover and heat production in tube-fed broiler chickens. Br. J. Nutr. 77:897-909. https://doi.org/10.1079/BJN19970088. 